\title{
BEVEZETŐ AZ ESZMECSERE ROVATHOZ
}

2010. április 23-án a Tanárképzők Akadémiája a bolognai rendszerbe illeszkedő tanárképzés problémáiról tartott szakmai tanácskozást. A megbeszélés kiinduló pontjául 3 meghívott előadó, Hatvani László, az MTA tanárképzési stratégiáját kidolgozó bizottságának elnöke, Csermely Péter, az államfó által felkért „Bölcsek Tanácsának" tagja, a Szárny és teher címủ munkaanyag oktatásfejlesztéssel és ezen belül a tanárképzéssel foglalkozó részének szerzője és Patkós András, a Bolyai Kollégium Baráti Körének elnöke ismertette a véleményét a tanárképzés jelenéről és jövőjéről, elsősorban a Bologna-folyamat szemszögéből. Ezt követően élénk vita alakult ki az akadémia résztvevői között. Ennek a vitának írásban is elküldött anyagát tartalmazza az Eszmecsere rovat. A szerkesztés során változtatás nélkül tárjuk az olvasók elé a különböző nézőpontokat, hozzászólásokat. A szakmai vitát nem kívánjuk sem összegezni, sem lezárni. Szívesen adunk teret a további megszólalóknak a folyóirat további számaiban.

(Megjegyzés: Csermely Péter előadása csak PPT formában állt rendelkezésünkre, de átfogó, szélesívü gondolatai miatt fontosnak tartottuk ily módon is a megjelentetését. Részletesebb tájékozódási lehetőséget nyújt maga a Szárny és teher kötet, amelynek hozzáférhetőségére utalás történik az előadás diáján is.) 